\title{
PENGAJARAN AKHLAK BERBASIS NASKAH SASTRA WULANG
}

\author{
Susiyanto $^{1}$
}

\begin{abstract}
Sastra Wulang is a Javanist literature masterpiece that consists of advices and various discussion related to ethics. Classical text is an essential heritage for Javanist society character development. As in this javanist poet masterpiece, It puts a good character as an underlined case.

Sastra Wulang often discusses the values that become javanest people believe, especially related to morality. Those values generally come from Islam, however, it is translated in order to be matched with the local context. With this method, thus the concepts taken from a religion would be more familiar and become a part of society understanding.

Therefore, discussing Sastra Wulang text in order to be recognized by young generation becomes an urgent problem. The purpose is to make the young generation can appreciate correctly the old era heritage. They will not only learn about cultural aspects, but at the same time, this method can also strengthen their understanding about Islam. The involvement of students in accessing sastra wulang activities, is expected that an education process conducted would be more comprehensive to combine a number of disciplines, such as the science of cultur, history, art, religion and other disciplines.
\end{abstract}

Keywords: sastra wulang, serat piwulang, cithakan, tedhakan

\section{ABSTRAK}

Sastra Wulang merupakan sebuah karya sastra di Jawa yang berisi nasihat-nasihat dan pembicaraan tentang etika. Genre naskah klasik ini merupakan warisan penting bagi pengembangan karakter masyakat Jawa. Sebab dalam karya para pujangga Jawa tersebut, persoalan akhlak mendapat penekanan penting.

Sastra wulang banyak mengangkat nilai-nilai yang menjadi pegangan masyarakat Jawa, terutama terkait dengan moralitas. Nilai-nilai tersebut secara umum bersumber dari agama Islam namun dibahasakan agar lebih sesuai dengan konteks lokalitas. Dengan cara ini maka konsep-konsep yang diturunkan dari agama akan lebih membumi dan menjadi bagian dari pemahaman masyarakat.

Maka, mengangkat kembali naskah sastra wulang agar dikenali oleh generasi muda menjadi persoalan yang cukup urgen. Tujuannya, agar mereka

Dosen Program Studi Pendidikan Agama Islam (PAI) Jurusan Tarbiyah Fakultas Agama Islam (FAI) Universitas Islam Sultan Agung (UNISSULA) Semarang 
mampu mengapresiasi secara tepat warisan dari masa lalunya. Mereka tidak hanya akan belajar aspek kebudayaan, namun pada saat bersamaan juga memperteguh pemahamannya tentang Islam. Dengan melibatkan peserta didik ke dalam aktivitas mempelajari sastra wulang, harapannya proses pendidikan akan berlangsung lebih komprehensif karena mengkombinasikan sejumlah disiplin ilmu antara lain budaya, sejarah, seni, dan agama serta disiplin keilmuan lainnya.

Kata kunci: sastra wulang, serat piwulang, cithakan, tedhakan

\section{A. PENDAHULUAN}

Perkembangan teknologi yang terjadi secara masif dan cepat di berbagai bidang tak ayal membawa perubahan gaya hidup. Tidak semuanya positif, namun tidak sedikit pula hal-hal negatif yang tumbuh sebagai konsekuensi kemajuan. Pada bagian ini dunia pendidikan sebagai "pengawal" proses pendidikan perlu menekankan kembali komitmen untuk membangun moralitas dan kepribadian peserta didik (Suryadi, 2012: 296; Tafsir, 2012: 49). Gerak laju jaman pada akhirnya menuntut kesiapan secara mental para peserta didik dalam menghadapi tantangan perubahan yang sukar diprediksi dan sepenuhnya berbeda.

Perembesan budaya dan nilai-nilai asing ke dalam wajah peradaban Islam adalah isu yang telah lama santer digaungkan. Bukan karena antipati terhadap perubahan, apalagi paranoid, namun upaya menjaga warisan tradisi (legacy) Islam sebagai bagian dari mekanisme survive agama menjadi topik menarik yang selalu hangat untuk diperbincangkan. Sebagian kalangan beranggapan bahwa konsep-konsep Islam telah mencukupi sebagai landasan pembentukan pribadi muslim yang kokoh dan tahan terhadap benturan dari anasir luar Sebagian lagi berupaya mendefinisikan ulang praktik keagamaan dengan sentuhan aspek lokalitas.

Bagaimanapun, rupanya, isu semacam itu selalu mendapat tempat. Sebab, hari hari terakhir ini umat telah menyaksikan proses-proses destruktif sedangan berjalan, mengikis, dan memangsa warisan tradisi agung yang telah mereka jaga sejak awal. Perubahan-perubahan semacam itu terus berlangsung baik diantispasi maupun tidak (Gazalba, 1973: 12-13, 91). Perlawananperlawanan kecil tidak lagi cukup untuk menghalau riak gelombang yang terus membesar.

Pembinaan akhlak merupakan salah satu dimensi keislaman yang mendapat tantangan cukup berat. Para peserta didik hari ini, di luar kegiatan belajar mengajar di lingkungan pendidikan formal dan non-formal, melalui banyak waktunya dengan dinina bobok-kan oleh teknologi. Lebih banyak menghabiskan waktunya dengan menonton televisi, mengakses gadget, atau 
kegiatan yang tidak menunjang produktivitas atau pembelajaran lainnya. Kalangan ini mendapatkan serbuan informasi secara masif tanpa kesiapan secara konseptual dan praktis untuk melakukan penyaringan.

Akibatnya, kemunduran akhlak menjadi salah satu persoalan yang paling sering dikeluhkan oleh para stake holder dunia pendidikan. Tidak mengherankan, dalam konteks keindonesiaan, pendidikan memiliki tugas embanan yang cukup berat diantaranya dalah peningkatan keimanan, ketakwaan, dan akhlak mulia. UUD 1945 dalam pasal 31 ayat 3 menyebutkan bahwa pemerintah memiliki tanggung jawab untuk mewujudkannya sebagai berikut: "Pemerintah mengusahakan dan menyelenggarakan satu sistem pendidikan nasional, yang meningkatkan keimanan dan ketakwaan serta akhlak mulia dalam rangka mencerdaskan kehidupan bangsa, yang diatur dengan undang-undang".

Oleh karena itu suatu usaha untuk menggali nilai-nilai yang berakar dari khazanah kebudayaan bangsa perlu dilakukan. Usaha ini diantaranya dapat ditempuh melalui proyek pendidikan dan kebudayaan untuk mengkonservasi nilai-nilai akhlak agar terwarisi oleh generasi berikutnya. Hal itu bisa dilakukan dengan menggali nili-nilai luhur masyarakat dari masa lampau melalui peninggalan naskah-naskah yang masih banyak diwariskan oleh institusi kraton di Jawa.

Pengenalan budaya di lingkungan institusi pendidikan hari ini, secara umum hanya sampai pada pengenalan wujud kebudayaan saja. Peserta didik belajar tentang bagaimana cara menari, melukis, menghapal lagu daerah, belajar bahasa lokal dan lains ebagainya. Namun sangat jarang para peserta didik tersebut dikondisikan untuk mendalami nilai-nilai budi pekeri yang telah merasuk ke dalam jiwa masyarakat masa lampau. Mereka adalah generasi pewaris bangsa maka mestinya mereka juga mewarisi nilai-nilai luhur yang dimiliki bangsanya tersebut. Pada bagian inilah pengkondisian peserta didik agar memahami dunia pernaskahan sejak awal menjadi relevan untuk dilakukan sembari diajari menghayati nilai-nilai kebaikan yang terkandung di dalamnya.

Urgensi dari kajian naskah tersebut dapat diamati dengan melakukan kajian secara mendalam. Hal itu akan memberikan kontribusi positif terhadap pembentukan nilai-nilai yang dianut oleh masyarakat sekaligus sebagai upaya sosialisasi terhadap pserta didik dalam pembentukan budi pekerti. Nilainilai yang berhasil diekstraksi dari sebuah naskah lantas diinternalisasi oleh masyarakat sehingga menghasilkan anggota masyarakat yang lebih beradab. Maka peran naskah klasik sebagai pemberi suluh (lentera) atau pepadhang (cahaya) akan dapat dibuktikan. Hal ini juga berfungsi untuk menciptakan ketahanan masyarakat dari pengaruh budaya Barat yang semakin mendesak identitas bangsa Timur. 
Sebuah nilai selalu bersumber dari sebuah pandangan hidup yang lahir dari suatu milliu tertentu. Dengan demikian sebuah nilai, sebenarnya merupakan produk dari sebuah kebudayaan. Nilai-nilai semacam itu akan mengalami proses pewarisan dari satu generasi kepada generasi selanjutnya. Proses sosialisasinya dilakukan melalui pergaulan yang melibatkan bahasa, baik secara tertulis maupun lesan (Suryani, 2012: 101-102).

Kesusatraan Jawa telah menyumbangkan banyak sekali produk dari tradisi tertulis yang mengandung nilai-nilai pengajaran bagi generasi bangsa. Melalui bidang kesusasteraan ini para budayawan memiliki peluang untuk menjabarkan nilai-nilai dari generasi terdahulu agar dapat diwarisi dengan baik oleh generasi muda. Dengan karya sastra tersebut, gagasan-gagasan tentang etika akan dapat diinternalisasi sehingga aspek lokalitas juga dapat dialih-generasikan. Pengkajian naskah karya sastra ini akan menjembatani tradisi lampau dan pelaku jaman ini agar terjadi koneksi dan sekaligus penanaman nilai (Hamid, 1989: 2). Dengan demikian karya sastra yang dikaji akan memperkokoh jati diri masyarakat dengan kebudayaan tertentu.

\section{B. NASKAH JAWA DAN PENGEMBANGAN AKHLAK}

Pengkajian dan pengaplikasian terhadap naskah-naskah yang mengandung nilai-nilai didaktis bisa menjadi alternatif pengajaran akhlak yang dikaitkan secara langsung dengan aspek lokalitas. Karya sastra yang dapat digunakan untuk kepentingan ini, salah satunya adalah karya sastra yang masuk dalam kategori serat piwulang atau sastra wulang. Naskah semacam ini secara khusus dapat diartikan sebagai "tulisan yang mengandung pelajaran atau hikmah".

Definisi Sěrat Piwulang sendiri adalah naskah atau karya sastra Jawa yang berisi pengajaran etika atau nasihat-nasihat luhur dengan menggunakan metrum tembang Jawa (Sukri, 2004: 78-79). Buku-buku piwulang yang memuat sastra wulang tersebut biasanya disusun dalam tembang macapat atau tembang lain yang sejenis. Naskah semacam ini biasanya memiliki fungsi yang sama dengan sebuah modul atau buku diktat tentang pengajaran nilai-nilai akhlak.

Secara umum naskah Serat Piwulang biasanya disusun dengan menggunakan aspek kebahasaan yang terikat dengan aturan-aturan ketat dari sastra Jawa. Hal ini tentu akan memerlukan langkah penafsiran tersendiri agar lebih mudah dipahami. Belum lagi penyampaian makna dan nilai dalam naskah tersebut biasanya juga diikat dengan metrum lagu macapat yang berupa guru gatra, guru wilangan dan guru lagu. Dalam mengakses isi naskah, seseorang juga diharuskan memahami nilai-nilai keislaman sebab secara umum naskah piwulang memang memiliki nafas Islam yang cukup kental. Belum lagi ungkapan-ungkapan tertentu juga harus dicari ekspresinya 
dalam aspek yang bersifat lokalitas, dalam hal ini dikaitkan secara langsung dengan budaya Jawa, sehingga proses pemaknaan terhadap sebuah karya sastra akan berjalan secara baik dan komprehensif.

Serat Piwulang merupakan karya sastra yang lahir dan berkembang antara abad ke-18 dan 19. Era ini digambarkan sebagai "masa kebangkitan" sastra Jawa sebab semangat untuk menggeluti tradisi penciptaan karya sastra mengalami peningkatan yang pesat dan dapat dibuktikan dengan banyaknya produk kesusateraan yang dihasilkan. Kota Yogyakarta dan Surakarta, yang sekaligus menjadi ibukota bagi dua kerajaan pewaris tradisi Mataram Islam di Jawa, merupakan pusat dari aktivitas pembentukan naskah-naskah Serat Piwulang tersebut. Banyak oengarang naskah yang sering dikenal sebagai "pujangga" tinggal di kedua kota tersebut, baik di lingkungan kraton atau luar (Rochkyatmo, 2010: 7; Widyawati, 2009: 32-33; Sukri, 2004: 16).

Serat-serat piwulang yang dihasilkan di kedua kota tersebut, lantas digunakan sebagai materi pengajaran akhlak di kalangan rakyat jelata. Dalam masa pemrintahan Pakubuwana VII, selain pembacaan Al Quran setiap Kamis malam yang dilaksanakan di lingkungan Kraton, juga ada tradisi pembacaan naskah karya sastra. Tradisi kedua ini biasanya melibatkan banyak anggota masyarakat. Dengan cara ini maka proses sosialisasi terhadap nilai-nilai luhur yang dikembangkan di lingkungan Kraton bisa tersebar luas di kalangan masyarakat. Pembacaan Al Quran biasanya dilakukan oleh abdi dalem ulama, sementara pembacaan naskah karya sastra dilakukan oleh para abdi dalem lainnya dengan diiringi tetabuhan seperti terbang atau sejenis rebana dalam tradisi Jawa (Soeratman, 1989: 100)

Pembacaan sastra wulang yang berkembang di kalangan masyarakat telah menjadi sebuah tradisi, bukan hanya dari lingkungan kraton namun juga menjangkau lingkup masyarakat yang luas, termasuk sampai pedesaan. Wujud kebudayaan semacam ini bahkan masih eksis hingga pertengahan abad ke-20. Fungsinya utamanya sebagai hiburan bagi abdi dalem dan sekaligus rakyat kecil. Berdasarkan pendapat Nancy K. Florida, sampai tahun 1960-an tradisi pembacaan naskah semacam itu masih dapat ditemukan. Acaranya biasanya diselenggarakan pada malam hari oleh "abdi wiraswara" yang berasal dari kalangan elit militer istana, yang secara bergantian melantunkan tembangtembang sepanjang malam. Acara tersebut berlangsung setiap malam kecuali hari Rabu dan Sabtu dimana mereka terlibat dalam kepanitaan pertunjukan wayang purwa. (Sukri, 2004: 77).

Dengan mengikuti kegiatan-kegiatan pentas seni semacam ini, mereka memiliki kemampuan untuk mengakses secara langsung terhadap naskah Serat Piwulang. Melalui pengembangan pembacaan naskah semacam itu maka isi dan kandungan nilai yang berasal dari naskah milik Kraton bisa menyebar ke dalam masyarakat. Rakyat kecil sekalipun dapat menikmati 
proses pembelajaran terhadap nilai-nilai yang diwarisi dari Islam dan sekaligus dari leluhurnya.

Untuk menyebarluaskan kandungan Serat Piwulang yang kaya dengan nilai-nilai akhlak yang luhur tentu membutuhkan suatu sistem pembelajaran. Hal ini dapat ditempuh melalui proses pendidikan yang ditujukan untuk menciptakan sebuah perubahan, baik dari sisi tingkah laku atau secara lebih luas mengarah pada pembentukan peradaban. Perubahan tingkah laku yang diharapkan nanti akan mencakup pula pengembangan aspek mental dan spiritual secara dinamis.

Ada beberapa sarana yang bisa dimanfaatkan untuk menyebarluaskan pembelajaran nilai dari naskah klasik semacam ini. Proses pembelajaran bisa dilakukan melalui kegiatan ekstra kurikuler yang menguatkan dan sekaligus dikuatkan melalui materi pelajaran seperti Bahasa Daerah, pendidikan Agama, dan ilmu-ilmu lain yang terkait.

\section{MENGGALI NILAI DARI NASKAH}

Tahap paling utama dan sekaligus urgen dalam kajian naskah, menurut Nabilah Lubis, adalah upaya untuk menelaah naskah dengan tujuan memahami budaya bangsa dan mengangkat nilai-nilai yang termaktub dalam isinya (1996: 51). Penulis mengidentifikasi langkah sebagai proses ekstraksi nilai yang dilakukan melalui proses penggalian sehingga dapat diperkenalkan ulang kepada masyarakat

Pada prinsipnya esktraksi atau upaya penggalian nilai dari sebuah karya sastra adalah tujuan umum dari disiplin ilmu filologi. Dalam proses tersebut maka nilai yang ada dalam teks yang berasal dari kebudayaan lama akan dapat diungkap kembali sebagai bekal untuk mengembangkan wujud kebudayaan alternatif selanjutnya (Lubis, 1996: 24). Melalui langkah ini maka nilai-nilai lama yang berasal dari masa lampau akan memperoleh saluran untuk diaktualkan kembali ke dalam kehidupan hari ini.

Upaya memperkenalkan kembali naskah bermuatan didaktik sebagai sumber material penanaman akhlak cukup beralasan dan perlu perhatian lebih lanjut. Para leluhur kita telah melaksanakan agama dalam kehidupan mereka sehari-hari. Upaya melaksanakan agama dengan biak ini tidak jarang melahirkan kreativitas-kreativitas abru dalam upaya pengamalan nilai-nilai yang terkandung dalam ajarannya. Kreativitas semacam ini pada dasarnya merupakan sebuah produk budaya yang harus dipahami oleh generasi selanjutnya, termasuk dalam pembudayaan terhadap aturan-aturan tentang etika dan akhlak.

Seorang pendidik memiliki peran dan fungsi untuk memfasilitasi agar peserta didik mampu menginternalisasi nilai-nilai yang dikategorikan sebagai akhlak mulia. Hal ini merupakan salah satu dari tujuan umum 
diberlangsungkannya proses pendidikan. Jadi tujuan pendidikan bukan sekedar membentuk ranah kecerdasan kognitif melalui teori-teori yang kering spiritualitas, namun juga berupaya membawa jiwa mereka agar menjadi insan kamil (manusia utama) yang memiliki akhlaqul karimah (akhlak yang mulia) (Daradjat, 1992: 29-31; Asy Syaibani, 1979: 416).

\section{ASPEK KEMANFAATAN}

Pengembangan akhlak dengan mengakses Serat Piwulang memiliki sejumlah manfaat. Adapun keuntungan yang diperoleh melalui aktivitas pembelajaran semacam ini antara lain adalah sebagai berikut:

Pertama, para peserta didik tidak hanya memahami wujud-wujud kebudayaan yang bersifat fisik saja seperti tari, rumah adat, senjata tradisonal, lagu daerah, pakaian adat, upacara adat, dan lain sebagainya. Melalui proses pembelajaran terhadap naskah Serat Piwulang tersebut maka peserta didik akan langsung bersentuhan dengan konsep-konsep akhlak luhur yang telah diformalisasikan oleh umat Islam pada masa lalu agar hidup dan berkembang dalam kebudayaan Jawa.

Di sini maka relasi antara pendidikan dan kebudayaan akan terlihat secara jelas dan dapat diterapkan dalam satu program. Tentu hal ini merupakan sebuah peluang yang perlu untuk ditindaklanjuti. Pendidikan merupakan salah satu sarana agar peserta didik mampu mendewasakan diri baik secara fisik, spiritual, maupun dari sisi pemikiran. Sementara kebudayaan merupakan kumpulan dari produk-produk hasil karya cipta, rasa, dan karsa manusia. Pendidikan sebenarnya merupakan salah satu cara untuk menghayati kebudayaan dan demikian juga sebaliknya. Dengan demikian maka pendidikan harus selalu diupayakan untuk mengikuti dan menyikapi perkembangan yang terjadi di sekitarnya. Di sana maka proses pendidikan berfungsi sebagai pengawal agar nilai-nilai yang ditawarkan tetap memiliki kandungan nilai-nilai positif dan sesuai dengan jati diri bangsa, dalam hal ini sesuai dengan ajaran Islam (Barnadib, 1990: 24).

Kedua, setelah melalui proses dan pengalaman dalam mengakses naskah maka peserta didik diharapkan akan dapat memiliki kemampuan yang bersifat teoritis maupun praksis tentang dunia pernaskahan. Untuk memahami suatu naskah, teutama naskah Serat Piwulang, peserta didik hendaknya memiliki sejumlah bekal kemampuan antara lain kemampuan membaca dan menulis dalam aksara lokal Jawa (hacaraka), kemampuan mengakses naskah, dan pemahaman agama, terutama ajaran Islam serta kemampuan lain yang dibutuhkan. Selanjutnya kemampuan-kemampuan itu sendiri akan dibentuk secara perlahan agar menjadi kemampuan peserta didik melalui praktik-praktik yang melibatkan mereka dalam kegiatan mengakses naskah. 
Ketiga, dari proses pembelajaran terhadap naskah tersebut, secara langsung maupun tidak langsung, peserta didik juga akan belajar tentang nilai-nilai yang ada dalam naskah Sastra Wulang. Dari proses pembelajaran ini mereka akan belajar tentang peninggalan masa lalu yang bersifat didaktis. Di situ mereka akan menyadari bagaimana pengalaman masa lalu ketika harus mempraktikkan akhlak Islam dalam kehidupan. Hasil praktiknya akan menciptakan ekspresi kebudayaan tertentu yang bisa dihayati oleh para peserta didik untuk memperkaya khazanah pemahaman mereka. Dari kegiatan ini maka akan diperoleh sejumlah manfaat, bukan hanya mendukung kegiatan pemantaban budi pekerti peserta didik, namun mereka mau tidak mau juga mempelajari agama dan kebudayaan pada kesempatan yang sama.

\section{E. TAHAP PENGENALAN}

Kegiatan mengenalkan naskah kepada para peserta didik ini akan dilakukan dalam sejumlah tahapan, antara lain adalah sebagai berikut:

Pertama, menurut Nabilah Lubis, upaya mengenalkan huruf, bahasa dan bidang-bidang keilmuan yang terkait adalah langkah awal yang harus dikuasai dalam mengakses naskah klasik (1996:42). Proses pemahaman terhadap huruf dan bahasa ini bisa dilakukan melalui pelajaran Bahasa Jawa atau ekstra kurikuler. Pendalaman lebih lanjut nanti akan diperoleh ketika peserta didik sudah terlibat dalam pembelajaran untuk mengakses naskah. Sejak awal para peserta didik tersebut harus dilibatkan agar muncul sikap-sikap dan kemampuan tertentu yang diharapkan yang timbul dari proses pembiasaan. Lembaga pendidikan yang ingin menerapkan metode semacam ini mestinya memiliki beberapa salinan teks yang bisa digunakan dalam proses pembelajaran.

Dalam pandangan A. Teeuw, upaya memberikan makna pada sebuah teks akan dapat dilakukan jika pembaca mampu memahami kode bahasa. Untuk kepentingan pengajaran akhlak bernasis naskah Sastra Wulang ini maka kode bahasa yang harus dipahami terletak dalam kode budaya yang ada di sekitar teks (1983: 12). Kode yang berasal dari budaya tersebut merupakan unsur ekstrinsik yang harus ditemukan dalam badan teks klasik sehingga lebih mudah untuk ditafsirkan. Untuk menjelaskan teorinya tersebut, Teeuw memberikan contoh dengan menggunakan kutipan yang berasal dari Serat Wedhatama, sebuah produk sastra wulang hasil kreasi K.G.P.A.A. Mangkunegera IV, raja dari Kraton Mangkunegaran di Surakarta. Dalam menafsirkan isi karya sastra seperti Serat Wedhatama ini tidak hanya ditentukan oleh pemahaman terhadap persoalan bahasa saja, - seperti urutan kata, diksi, susunan kalimat, aspek bunyi, tata bahasa - tetapi juga meliputi aspek kebudayaannya (1983: 13-14).

Adapun bait yang dikutip oleh Teeuw dari Serat Wedhatama tersebut adalah sebagai berikut: 
"Mingkar-mingkuring angkara,

Akarana karenan mardi siwi

Sinawung resmining kidung,

Sinuba sinukarta

Mrih kretarta pakartining ngèlmu luhung

Kang tumrap nèng tanah Jawa

Agama ageming aji”

Kutipan itu diterjemahkan oleh S.Z. Hadisutjipto sebagai berikut, "Menjauhkan diri dan menyingkiri sifat-sifat mementingkan kepentingan pribadi. Sebabnya ialah karena ingin memperoleh kepuasan dari hasil mendidik anak. Yang dirangkai dalam sebuah kidung yang mengasyikkan; digubah dengan baik dan seindah mungkin. Tujuannya ialah agar supaya budi pekerti yang berdasarkan ilmu yang tinggi dan mulia diterapkan di Pulau Jawa; yakni ilmu agama, yang menjadi pegangan raja dapat terlaksana sebaik-baiknya".

Dalam pandangan Teeuw, walaupun naskah-naskah tersebut bisa dengan mudah dibaca dan dipahmi oleh masyarakat yang menggunakan Bahasa Jawa, namun untuk menafsirkan dan mengetahui keseluruhan maknanya secara tepat, pemahaman terhadap konteks kebudayaan yang berkembang di sekitar masa penyusunan teks benar-benar diperlukan (1983: 13). Sejumlah konsep seperti ngelmu luhung (ilmu yang luhur), angkara, dan lain sebagainya semstinya bisa dimaknai dengan menghayati spirit yang berkembang pada jaman pembentukan karya sastra.

Kedua, langkah berikutnya adalah upaya untuk memahami ilmu bantu sehingga upaya memahami naskah akan dapat dilakukan oleh para peserta didik. Mereka bukan hanya harus mempelajari aksara dan bahasa Jawa, namun pemikirannya harus pula diarahkan untuk mendalami adat istiadat dan sekaligus agama. Pemahaman terhadap latar adat istiadat dan agama ini diperlukan untuk memahami unsur-unsur ekstrinsik di sekitar naskah, seperti status sosial pengarang, profesi, semangat jaman, dan budaya yang berkembang selama kehidupannya.

Serat Wulang, yang umumnya dikarang di kedua lingkungan atau wilayah Kraton Yogyakarta dan Surakarta, adalah naskah bernafas keagamaan Islam. Dengan latar belakang semacam ini maka pemahaman agama juga diperlukan agar penafsiran terhadap teks dapat dilakukan dengan baik. Isi bahasan naskah Serat Wulang yang lebih mengarah pada persoalan etika, mau tidak mau juga menuntut penafsir agar mendalami bentul persoalan etika ini terutama yang berkembang dalam sejarah sosial keagamaan di masa penulisan teks. Melalui pembacaan teks peserta didik juga diajak untuk melakukan perenungan terhadap nilai-nilai luhur yang 
mereka peroleh selama proses mengakses naskah. Nilai-nilai ini lantas diinternalisasi agar dapat diambil manfaatnya dalam mempertinggi kualitas budi pekerti masing-masing peserta didik.

Mengingat kandungan agama yang relatif besar dalam naskahnaskah Sastra wulang, maka pemahaman terhadap konsep-konsep agama akan menunjang proses penafsiran secara signifikan. Melalui kajian terhadap naskah ini maka beberapa keuntungan sekaligus dapat diperoleh. Beberapa keuntungan itu antara lain adalah peserta didik yang bisa dikondisikan untuk memahami nilai-nilai agama, mereka paham dengan karya sastra dan budaya serta aspek kebahasaan. Sekaligus menginternalisasi nilai-nilai akhlak sehingga memberikan sumbangsih bagi pembentukan karakter positif anakanak bangsa.

\section{F. PROSES PEMBIASAAN}

Konsep pendidikan dengan menggunakan Serat Piwulang ini juga disertai dengan pengembangan kebiasaan baik para peserta didik. Kebiasaan semacam ini dibentuk melalui proses pembiasaan secara sistematis untuk menunjang kemampuan para pembelajar dalam mengakses isi dan kandungan naskah yang mereka teliti. Internalisasi akhlak mulia akan diperoleh melalui penghayatan terhadap nilai-nilai luhur yang termaktub dalam naskah klasik. Di sinilah penghayatan terhadap nilai untuk memahami kedalaman makna yang terkandung di dalamnya juga dibarengi dengan proses-proses pembiasaan.

Ibn Miskawaih (330 - 421H / 941 - 1030), akhlak lebih merupakan keadaan jiwa yang memberikan dorongan untuk melakukan tindakan tanpa melalui banyak proses pemikiran. Pada bagian ini pertimbangan untuk melakukan tindakan bisanya tidak terlalu banyak dilakukan karena telah berjalan secara refleks akibat pola internalisasi nilai-nilai yang sebelumnya telah dilakukan. Nilai-nilai tersebut biasanya telah mengalami proses kristalisasi menjadi tabiat dalam diri manusia dan menjadi bagian dari karakteristik baiknya (Ibn Miskawaih, 1994: 56).

Keadaan jiwa yang membentuk akhlak tersebut antara lain adalah sebagai berikut: (1) Bersifat alamiah, yaitu keadaan jiwa yang secara lalami telah dibawa seseorang sejak lahir. Sebagai contoh ada orang-orang tertentu yang mudah meletup emosinya hanya karena persoalan yang sedehana atau seseorang yang merasa kaget hanya karena suara-suara yang sebenarnya relatif kurang keras; (2) terbentuk melalui proses latihan dan pembiasaan. Pada bagian kedua ini seseorang yang telah melakukan pekerjaan tertentu dalam jangka waktu yang lama dan terjadi secara kontinu biasanya akan membentuk kebiasaan. Dalam pembentukan kebiasaan semacam ini, awalnya dimulai dari tindakan-tindakan yang dipikirkan atau dipertimbangkan,. Setelah diulang berkali-kali maka seseorang biasanya akan tidak akan lagi merasa berat untuk 
melakukan tindakan yang sama. Demikian juga keadaan jiwa bisa terbentuk melalui proses semacam ini, yaitu melalui pelatihan dan pembiasaan.

Pembiasaan dalam program ini dilakukan dengan melibatkan para peserta didik untuk mengakses naskah. Lembaga penyelenggara pendidikan yang mengembangkan pengajaran akhlak berbasis naskah mestinya telah menyiapkan salinan naskah baik yang berasal dari tedhakan (naskah yang disalin dengan menggunakan tulisan tangan) maupun cithakan (naskah yang sudah dipublikasikan dengan diterbitkan). Ketsersediaan naskah ini sangat penting untuk menunjang proses pembiasaan dan pelatihan bagi para peserta didik dalam mengakses manuskrip.

Pelibatan para peserta dalam sejumlah aktivitas kesenian yang menunjang, seperti keikutsertaan dalam pentas seni tembang Jawa yang melagukan syair-syair dalam naskah piwulang, sangat diperlukan untuk mendukung keberhasilan program ini. Misalnya kegiatan pentas seni pertunjukan wayang, santiswaran dan lain sebagainya.

Aktivitas outing class (di luar kelas) seperti kunjungan ke perpustakaan Kraton atau museum yang menyimpan naskah juga perlu dilakukan. Hal ini akan membentuk sikap menghargai dalam diri peserta didik terhadap warisan adiluhung bangsanya. Jika perlu mereka juga perlu dilibatkan dalam upaya "berburu" naskah klasik yang masih banyak dipelihara oleh masyarakat maupun yang sudah diterbitan oleh publisher. Kegiatan semacam ini bukan hanya mengajarkan spirit konservasi terhadap naskah klasik, namun juga membentuk sikap cinta terhadap naskah dan pada giliran selanjutnya mereka bisa membantu pihak-pihak berwenang untuk menjaga khazanah kekayaan bangsanya.

Mereka juga harus dilibatkan dalam proses pemeliharaan naskah. Hal ini setidaknya bisa ditempuh pula melalui satu program pelatihan saja sebab tujuannya sekedar memperkenalkan kemampuan dasar. Mereka juga harus dipahamkan bahwa bahwa naskah yang rata-rata terbuat dari material bahan cepat rusak memiliki kelemahan dari sisi waktu (pelapukan), kelembaban, bencana alam, jamur, dan lain sebagainya. Akses yang kurang hati-hati bisa menyebabkan kerusakan parah pada naskah-naskah lama. Selan itu juga perlu diajari tentang bagaimana membuat back up naskah dengan melalui proses penyalinan maupun penerbitan, melakukan, foto dokumen, men-scanning, dan pembuatan micro-film naskah.

Melalui berbagai upaya di atas, maka diharapkan kelestarian naskah kalsik Jawa akan terjaga di tangan para generasi pewarisnya. Dengan menggugah kesadaran para pelajar untuk mencintai naskah, maka akan semakin banyak naskah dapat dikonservasi. Jejak sejarah dan spirit yang telah diwariskan para pendahulu akan terus terjaga dalam jiwa para taruna muda. Di sanalah jati diri bangsa akan tetap terjaga. 


\section{G. PENUTUP}

Tawaran konsep Pendidikan Berbasis Sastra Wulang di atas diharapkan akan menjadi sebuah wujud kepedulian dan sumbangan dalam upaya pengembangan kepribadian bangsa. Meski menggunakan sejumlah terminologi "Jawa", namun program seperti ini tetap bisa diterapkan dalam masyarakat dengan kebudayaan yang lain dengan tetap mempertimbangkan aspek lokalitas. Tentu ada sejumlah perbedaan yang membutuhkan penyesuaian di sini.

Melalui proses yang telah dibahas sebelumnya maka pengembangan akhlak generasi muda dapat dilakukan melalui beberapa jalur diantaranya, Pertama, memebrikan kesempatan bagi peserta didik untuk menghayati kebudayaan masa lalunya sehingga dapat digunakan sebagai modal untuk mengkonservasi dan mengembangkan nilai positif dalam tradisi bangsa; Kedua, peserta didik diarahkan untuk menjadi anak bangsa yang sadar sejarah; Ketiga, mereka juga dilibatkan dalam kegiatan yang menumbuhkan rasa cinta terhadap kesenian yang berfungsi untuk memperhalus jiwa dan rasa; Keempat, di dalam penghayatan terhadap Serat Wulang peserta didik juga diarahkan untuk mendalami dan menghayati nilai-nilai akhlak yang bersumber dari agama yang dianutnya, dalam hal ini secara khusus adalah ajaran Islam.

Dengan keikutsertaan mereka dalam program berinteraksi dengan naskah Sastra Wulang, diharapkan proses pendidikan yang bersifat komprehensif akan dapat dijalankan yaitu dengan mengkombinasikan pemahaman terhadap ilmu pernaskahan, ilmu budaya, kesenian, dan sekaligus agama Islam serta ilmu atau kemampuan pendukung lainnya. Dengan demikian proses pendidikan untuk mencetak manusia dengan sejumlah talenta yang terasah dan sekaligus berakhlak mulia.

\section{DAFTAR PUSTAKA}

Al-Sayibany, Omar Muhammad Al-Toumy, 1979, Falsafah Pendidikan Islam, Terjemahan dari Falsafat At-Tarbiyah Al-Islamiyah, Jakarta: Bulan Bintang

Barnadib, Imam, 1990, Filsafat Pendidikan: Sistem dan Metode, Cetakan VI, Yogyakarta: Andi Offset

Daradjat, Zakiah, 1992, Ilmu Pendidikan Islam, Cetakan II, Jakarta: Bumi Aksara

Gazalba, Sidi, 1973, Modernisasi dalam Persoalan: Bagaimana Sikap Islam?, Jakarta: Bulan Bintang 
Hamid, Ismail, 1989, Kesusasteraan Indonesia Lama Bercorak Islam, Jakarta: Penerbit Pustaka Al Husna

Lubis, Nabilah, 1996, Lubis, Naskah, Teks dan Metode Penelitian Filologi, Jakarta: Fakultas Adab IAIN Syarif Hidayatullah

Miskawaih, Ibn, 1994, Menuju Kesempurnaan Akhlak: Buku Daras Pertama tentang Filsafat Etika, Terjemahan dari Tahdzib Al-Akhlaq, Bandung: Mizan

Rochkyatmo, Amir, 2010, Sastra Wulang, Sebuah Genre di Dalam Sastra Jawa dan Karya Sastra lain Sejaman, dalam Jurnal JUMANTARA Vol. 1 No. 1 Tahun, Jakarta: Perpustakaan Nasional RI

Soeratman, Darsiti Soeratman, 1989, Kehidupan Dunia Kraton Surakarta 1830-1939, Yogyakarta: Penerbitan Tamansiswa

Sukri, Sri Suhandjati, 2004, Ijtihad Progresif Yasadipura II dalam Akulturasi Islam dengan Budaya Jawa, Yogyakarta: Gama Media

Suryadi, Ace, 2002, Pendidikan, Investasi SDM, dan Pembangunan: Isu, Teori, dan Aplikasi, Cetakan II, Jakarta: Balai Pustaka

Suryani, Elis, NS, 2012, Filologi, Bogor: Ghalia Indonesia

Tafsir, Ahmad, 2012, Filsafat Pendidikan Islami, Cetakan V, Bandung: Rosdakarya

Teeuw, A., 1983, Membaca dan Menilai Sastra: Kumpulan Karangan, Jakarta: Gramedia

Widyawati, Wiwin, R., 2009, Serat Kalatidha: Tafsir Sosiologis dan Filosofis Pujangga Jawa Terhadap Kondisi Sosial, Yogyakarta: Pura Pustaka 